J. Product. \& Dev., 23(1): 111-134 (2018)

\title{
EFFECT OF ORGANIC AND BIO-FERTILIZATION ON VEGETATIVE GROWTH, YIELD, AND FRUIT QUALITY OF 'VALENCIA' ORANGE TREES
}

\author{
Ahmed A. El-Aidy; Shamel M. Alam-Eldein and Waleed M. Esa \\ Department of Horticulture, Faculty of Agriculture, Tanta University Tanta, \\ 31527, Egypt.
}

\begin{abstract}
This work was carried out during 2013/2014 and 2014/2015 seasons on 40 years old 'Valencia' orange Citrus sinensis (L) Osbek trees grown in light clay soil at a private orchard in Algharbia Governorate, Egypt. The aim of this work was evaluate the effect of organic fertilizater (compost) and biological fertilizater (TS; Bacillus circulance, Bacillus poylmyxa , Candida spp , Trichoderma spp, Bacillus megatherium) on vegetative growth, yield and fruit quality of Valencia orange trees, as a partial replacement of mineral fertilization.
\end{abstract}

Results indicated that the application of half nutrient requirements as mineral NPK and the other half from organic source ( compost) in combination with 150 or $200 \mathrm{ml}$ TS showed the best results in terms of vegetative growth, yield, and fruit quality. This result confirm the role of organic and biofertilization on plant growth, development, productivity, and fruit quality, compared to the sole use of NPK fertilizers (control), or even when mixed with organic fertilizers. It should also be noticed that the most pronounced effect of the three combined fertilizers was gained by high rates of biofertilizers $200 \mathrm{ml}$. T.S.

Conclusively, results for sure do not nullify the important role of NPK fertilization; instead they revealed that minimizing NPK level to the half in combination with organic and bio-fertilizers was so effective.

Key words: Orange, compost, biofertilization, vegetative growth, yield, fruit quality

\section{INTRODUCTION}

The word citrus is derived from the Latin cedrus that comes from the Greek kedrus, which refers to the kedromelon or cedar-apples (citron) (Jahoda, 1976). Citrus fruit are members of Rutaceae family, which include orange, grapefruit, lemon, lime, tangerine and mandarin, pummelo, and kumquat. It is generally accepted that pummelo, mandarin, and citron are 
the founding true species of all citrus varieties existing today (Spiegel- Roy and Goldschmidt, 1996). The targeted cultivar of this study is 'Valencia' orange Citrus sinensis (L.) Osbeck (Hodgson, 1967).

Citrus is commercially grown primarily in regions with mild winters located between $20^{\circ}$ and $40^{\circ}$ of latitude in both hemispheres (McKnight and Hess, 2000). Citrus is second after grapes in planting and production of perennial fruits worldwide (Spiegel- Roy and Goldschmidt, 1996). Egypt is considered the sixth largest world producer after Brazil, China, USA, EU, and Mexico. Egypt ranked the sixth in world citrus and orange and the third world production in mandarin (FAO, 2017)

Fruit quantity and quality are affected by several factors including cultivar, rootstock, climate, soil, pests, irrigation, and nutrition. Therefore, supplying sufficient nutrition and using sound irrigation scheduling techniques should be high-priority management practices for every grower for expected yield and fruit quality. The most important management practices include irrigation, in addition to nitrogen, phosphorus, potassium, and magnesium nutrition. Some micronutrients, like boron and copper, can also affect fruit quality, but only if they are deficient in the soil and tree. In general, when any nutrient element is severely deficient, fruit yield and quality will be negatively affected (Zekri et al., 2003). The use of organic and bio-fertilizers has been increased in recent years for their positive effects on soil and plant growth and productivity, in addition to the lower cost and less hazardous effects, compared to chemical fertilizers (Shiralipour et al., 1992).

Organic fertilizers and humic acid significantly decreased fruit nitrate and nitrite content, and improved yield and fruit quality of the treated vines and soybean (Saleh and Ahmed, 1988; Farag, 2006).

Organic matter content of compost is high and often improves soil physical, chemical, and biological characteristics. Compost provide a stabilized form of organic matter that improves nutrient content, water holding capacity, cation exchange capacity, soil pore space, and aggregate stability (Shiralipour et al., 1992). Also, (Aseri et al., 2008) found that the use of bio-fertilizers significantly improve yield and fruit quality of pomegranate in India. It also enhanced the concentration of various nutrients, and soil microbial activity. Bio-fertilization is also considered a positive alternative to chemical fertilization to enhance citrus yield and fruit quality, because it are safe for human, animal, and environment. Using biofertilizers in organic food production was accompanied with the reduction of environmental pollution. it increase $\mathrm{N}$ fixation and enhance 
nutrients uptake, as well as the stimulation of natural hormones biosynthesis and the production of antibiotics (Subba-Rao et al., 1993).

Therefore, the aim of this study was to provide the best combined application of mineral, organic, and bio- fertilization that could be used to gradually replace regular mineral fertilization programs and to improve the vegetative growth, productivity, and fruit quality of 'Valencia' orange trees.

\section{MATERIALS AND METHODS}

This study was carried out during 2013/ 2014 and 2014 / 2015 seasons on 40 years old 'Valencia' orange, Citrus sinensis,(L) osbek budded trees on sour orange rootstock, Citrus aurantium, and grown in a private citrus orchard located at Meat lait Hashem in AlMahalla AlKubra, district Algharbia, Governorate, Egypt. Trees were planted at $5 \times 5 \mathrm{~m}$ apart with a total number of 168 trees/Faddan in a light clay soil.

\section{Common agricultural practices during both seasons:}

\section{The irrigation method is the surface irrigation of river water :}

\section{Fertilization :}

Three different types of fertilizers were used;

1- NPK (ammonium nitrate [33.5\% N], potassium sulphate [48.5\% $\mathrm{K}_{2} \mathrm{O}$ ], and superphosphate $\left[15.5 \% \mathrm{P}_{2} \mathrm{O}_{5}\right]$ ) were added each season, as follow;

- Both superphosphate (100 kg/faddan) and sulfur (200 Kg/faddan) were scattered around the tree shade in late winter.

$\mathbf{N}$ fertilizer was added three times:

- During the first week of March (early spring) of both seasons, trees received $200 \mathrm{~kg} / \mathrm{feddan}$ ammonium nitrate and $100 \mathrm{~kg} / \mathrm{feddan}$ potassium sulfate [48.5\%].

- Another $150 \mathrm{~kg} /$ feddan of ammonium nitrate was added in May after fruit set.

- Fertilization was repeated again in July of both seasons by adding 200 $\mathrm{kg} / \mathrm{feddan}$ ammonium nitrate and $100 \mathrm{~kg} / \mathrm{feddan}$ potassium sulfate/tree.

2- Organic fertilizer as compost (mixture of rice straw and animal manure) was added before irrigation by scattering it around the tree trunk (15 $\mathrm{kg} /$ tree/season) during the first week of March (early spring).

3- Bio-Fertilizer (TS) [Bio-enriched fluid of Bayutk Company consists of Bacillus Circulance, Bacillus Poylmyxa, Candida spp., Trichoderma spp., and Bacillus Megatherium] was add around the tree trunk after 24 hours of irrigation, during the first week of March (early spring) at a 
level of 100, 150, and $200 \mathrm{ml}$ per tree. This fertilization program was applied in both seasons in the same dates.

- Weeds were mechanically removed in March, April, and May, and chemically controlled using 48.5\% Herbozd herbicide in June, July and August.

- The following micronutrients were sprayed in May and June; amino acids $(7.42 \%)$, iron $(1.2 \%)$, zinc $(0.8 \%)$, manganese $(1 \%)$, boron $(0.1 \%)$, and molybdenum $(0.1 \%)$.

- Tree stem was sprayed, in mid-September, for silver leaf whitefly (Bemisia argentifolii ) control using a mixture of $10 \%$ Lambda pesticide $(1.25 \mathrm{Kg} /$ 600 liters water) and Malathion pesticide (1 liter/600 liters water).

\section{Experiment}

Forty eight trees were selected for this experiment, and grouped in 8 treatments. Each treatment was represented by 6 trees in 3 replicates, with 2 trees each. Fertilization treatments can be summarized, as follow:

$\mathbf{T 1}=$ Full amount NPK (control), $\mathbf{T} 2=$ Full amount compost, $\mathbf{T} 3=$ Full amount compost $+100 \mathrm{ml}$ TS, T4= Full amount compost $+150 \mathrm{ml} \mathrm{TS}, \mathbf{T 5}=$ Full amount compost $+200 \mathrm{ml}$ TS, T6= Half amount NPK + half amount compost $+100 \mathrm{ml} \mathrm{TS}, \mathbf{T} 7=$ Half amount NPK + half amount compost +150 $\mathrm{ml}$ TS, T8= Half amount NPK + half amount compost $+200 \mathrm{ml}$ TS.

\section{Soil and compost analysis}

Soil samples were collected at $(30-60 \mathrm{~cm})$ depth from the experimental orchard. Compost samples were also collected, and both type of samples were sent for analysis at the Soil Sciences Department, Faculty of Agriculture, Kafrelsheikh University. Samples were air-dried and sieved using a $2.0 \mathrm{~mm}$ sieve. Chemical characteristics were carried out using 1:5 sample to water solution. Total nitrogen content was determined using micro-kjeldahl method as described by (Pregle, 1945). Phosphorus percentage was determined colorimetrically, as described by (Murphy and Riley, 1962). Potassium percentage was also determined using the flame photometric method described by (Brown and Lilleland, 1974). Micronutrients, such as $\mathrm{Mn}, \mathrm{Zn}, \mathrm{Cu}$, and $\mathrm{Fe}$ were determined using Perkin Elmer atomic absorption spectrophotometer according to (Wilde et al., 1985). Soil and compost analysis results are shown in Table 1.

\section{Data recorded as follows :}

Determination of NPK \& micronutrients in leaves:

To determine leaf mineral content, forty leaves were collected in September from non-fruiting shoots that were previously tagged during the spring growth cycle (Jones and Embleton, 1960). Leaves were washed with 


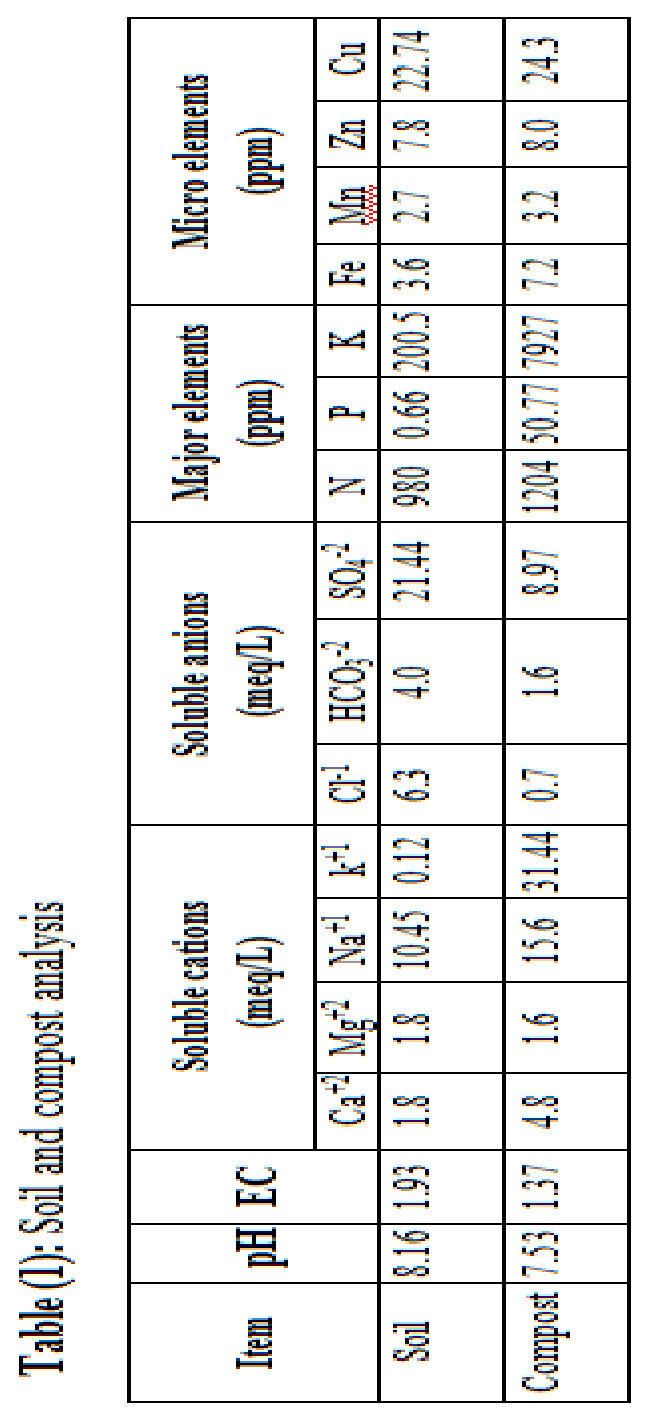


tap water followed by distilled water, and leaf fresh weight was calculated. Leaves were oven dried at $70^{\circ} \mathrm{C}$ until constant weight. Leaf dry weight was calculated, and then dry leaves were finely ground. Samples of $0.1 \mathrm{~g}$ from each leaf sample were wet digested using a 5:1 mixture of concentrated $\mathrm{H}_{2} \mathrm{SO}_{4}+$ perchloric acid $\left(\mathrm{HCLO}_{4}\right)$ to determine total nitrogen using the micro-kjeldahl method. Nitrogen, phosphorus, and potassium percentage was determined using the same methods used in soil samples. The amount of micronutrients, such as $\mathrm{Mn}, \mathrm{Zn}, \mathrm{Cu}$, and $\mathrm{Fe}$ were determined according to the methods described by (Cottenie et al., 1982).

\section{Growth aspects:}

1. Shoot number and length: Four main branches; one toward each direction, approximately uniform in length and diameter, were selected on each tree at early spring of both seasons. All growing spring shoots were labeled and monitored monthly from April $1^{\text {st }}$ to November $1^{\text {st }}$ for average shoot number and length per main branch.

2.Tree size $\left(\mathbf{m}^{2}\right)$ : This was calculated according to Morse and Robertson (1987) as follow equation:

$$
\text { Tree size }=0.5236 \times \mathrm{HD}^{2} \text {; }
$$

Where $\mathrm{H}=$ tree height, and $\mathrm{D}=$ tree diameter.

3. Leaf number: Number of leaves on the selected four branches was counted, and the mean number was calculated out (Chou, 1966).

4. Leaf area $\left(\mathbf{c m}^{2}\right)$ : Six months after the end of spring growth, forty leaves were collected in September during both seasons. Leaves collection started at the fourth leaf on the branch from all four directions of the tree, and leaf area was calculated according to Chou(1966) as follows equation:

Leaf area $=2 / 3$ leaf length $\times$ leaf width.

5. Chlorophyll content: By the end of spring growth cycle in September, fresh leaf samples were collected from all four directions of each tree. Leaf collection started at the fourth leaf from the top of non-bearing shoots only. Leaves were washed three times with tap water, and then washed using distilled water to measure total chlorophyll, and both chlorophyll (a) and (b). Values were calculated as $\mu \mathrm{g} / \mathrm{cm}^{2}$ according to Moran (1982). Chlorophyll (a) and (b) were calculated by the following equation:

Chlorophyll (a) or (b) $\left[\mu \mathrm{g} / \mathrm{cm}^{2}\right]=$ Reading $(\mu \mathrm{g} / \mathrm{ml}) \times$ Extracted volume $(\mathrm{ml})$

$$
\text { Leaf area }\left(\mathrm{cm}^{2}\right)
$$


Total chlorophyll $=$ Chlorophyll $(\mathrm{a})+$ Chlorophyll $(\mathrm{b})$.

\section{Fruiting and fruit quality}

1. Fruit set (\%): Fruit set was calculated two weeks after full bloom in April during both seasons using the following equation;

$$
\text { Fruit set }(\%)=\frac{\text { Total fruit number } \times 100}{\text { Total flowers number }}
$$

The percentage of remaining fruit was calculated again after June drop using the following equation:

Final Fruit set $(\%)=$ Number of remaining fruit after June drop x 100

$$
\text { Total flowers number }
$$

2. Total Yield: Total yield $(\mathrm{kg})$, average fruit weight $(\mathrm{g})$, and fruit number per tree were calculated at harvest time (first week of May in both seasons).

3. Peel thickness: The average thickness of the peel $(\mathrm{mm})$ was measured according to Kwan, (2011).

4. Juice Volume: Four random fruits are taken from each treatment and then squeezed with a hand-squeezer. Juice was collected in a flask, and juice volume was record and then seeds were removed.

5. Total soluble solids (TSS): It was measured using a refractometer, according to A.O.A.C.(1995).

6. Total acidity: Juice samples was filtered and used to determine total acidity using the titration method against $\mathrm{NaOH}(0.1 \mathrm{~N})$ in the presence of phenol phethalein, as an indicator, according to (Chen and Mellenthin (1981) to calculate citric acid (mg) per100 ml juice.

7. Ascorbic acid (Vitamin C) content: This was determined in filtered juice samples and expressed as $\mathrm{mg} / 100 \mathrm{ml}$ juice, as described by A.O.A.C.(1995) using $5 \mathrm{ml}$ juice sample and $5 \mathrm{ml}$ of oxalic acid solution $(2 \%)$, and then titrated against 2,6-dichlorophenolendophenol indicator dye to the end point (the appearance of pink color) to calculate vitamin $\mathrm{C}$.

\section{Statistical analysis}

Data were analyzed using M-Stat program in a randomized complete block design (RCBD) as described by Snedecor and Cochran (1980), and means were compared using least significance difference (LSD) at $\mathrm{P} \leq 0.05$ (Little and Hills, 1972). 


\section{RESULTS AND DISCUSSION}

Shoot number, shoot length $(\mathrm{cm})$, and tree size $\left(\mathrm{m}^{3}\right)$ :

Results in Table (2) indicate that the application of half amount NPK and half amount compost in combination with 100,150 or $200 \mathrm{ml}$ TS significantly affected both shoot number and length of 'Valencia' orange trees, a well as , tree size in comparison to the control during both seasons. Anyhow , application of full amount of compost enriched with 100, 150 or $200 \mathrm{ml}$ TS has slightly affected all vegetative growth characters . In this regards, control recorded the lowest values of all three parameters compared to other treatments during the two seasons .

Previous reports revealed that organic fertilization positively affected vegetative growth traits of 'Satsuma' mandarin (Eghaball and Power, 1994), sweet orange (Mourafilha et al., 1998), acid lime (Hiwarale et at., 2004), 'Washington' navel orange (El-Kobbia, 1999), sour orange (El-Morshedy, 1997), 'Le- Conte" pear seedlings (Eissa et al., 2007a; Ismail et al., 2007), guava (Yadav et al., 2012), 'Dashehari' mango (Mohit and Kumar, 2013), and 'Picual' olive (Safar and Ahmed, 2012).

Results showed a positive effect of combined application of NPK, organic, and bio- fertilization, also compared to the control. The interaction between organic and bio- fertilizers was evident, and significantly improved shoot length, shoot number per tree, and hence tree size.

Such findings were in parallel with those reported on 'Balady' mandarin (Ebrahiem and Mohamed, 2000), 'Balady' guava (Osama et al., 2016), 'Sukary' mango (Faissal et al., 2015b), 'Washington' navel orange (Abdelaal et al., 2010), mango and avocado (Abd-Rabouo, 2006), olive (Faissal and EL-Dawwy, 1999), and grapes (Ahmed et al., 1997). Biofertilization provides suitable amount of nitrogen to the plant. Nitrogen is a main component of protein, protoplasm, chlorophyll, and DNA. It plays an important role in cell division, and therefore improves vegetative growth and increases tree size throughout increasing shoot number and length (Oparka, 1993).

\section{Leaf number and leaf area $\left(\mathrm{cm}^{2}\right)$ :}

Data of Table (3) clarify significant effect related to the combined application of half amount of NPK and half amount of compost, with either 100,150 or $200 \mathrm{ml} \mathrm{TS}$. The effect of these treatments has extented to leaf area and number compared to the control which recorded the lowest leaf number and area in both seasons. These results were closed to previous which findings indicated that biofertilization had significantly increased 
Table 2: Effect of different fertilizer treatments on vegetative growth characteristics of 'Valencia' orange trees during 2013/2014 and 2014/2015 seasons.

\begin{tabular}{|c|c|c|c|c|c|c|}
\hline \multirow[b]{2}{*}{ Treatment } & \multicolumn{2}{|c|}{ Shoot number } & \multicolumn{2}{|c|}{ Shoot length (cm) } & \multicolumn{2}{|c|}{ Tree Size $\left(\mathrm{m}^{3}\right)$} \\
\hline & $\begin{array}{c}2013 / \\
2014 \\
\end{array}$ & $\begin{array}{c}2014 / \\
2015\end{array}$ & $\begin{array}{c}2013 / \\
2014\end{array}$ & $\begin{array}{c}2014 / \\
2015\end{array}$ & $\begin{array}{c}2013 / \\
2014\end{array}$ & $2014 / 2015$ \\
\hline Full NPK (Control) & $6.83 \mathrm{c}$ & $7.80 \mathrm{~b}$ & $9.533 \mathrm{c}$ & $10.70 \mathrm{~b}$ & $10.06 \mathrm{ab}$ & $10.73 \mathrm{c}$ \\
\hline Full compost & $8.000 \mathrm{abc}$ & $8.00 \mathrm{~b}$ & $10.00 \mathrm{~b}$ & $11.60 \mathrm{ab}$ & $10.18 \mathrm{ab}$ & $10.96 \mathrm{bc}$ \\
\hline Full compost $+100 \mathrm{TS}$ & $8.20 \mathrm{abc}$ & $8.20 \mathrm{~b}$ & $10.07 \mathrm{~b}$ & $12.37 \mathrm{a}$ & $9.177 \mathrm{~b}$ & $11.55 \mathrm{abc}$ \\
\hline Full compost $+150 \mathrm{TS}$ & $7.16 \mathrm{bc}$ & $8.46 \mathrm{~b}$ & $11.50 \mathrm{a}$ & $11.70 \mathrm{ab}$ & $10.34 \mathrm{ab}$ & $11.24 \mathrm{bc}$ \\
\hline Full compost $+200 \mathrm{TS}$ & $8.40 \mathrm{ab}$ & $9.56 \mathrm{a}$ & $10.23 \mathrm{~b}$ & $11.73 \mathrm{ab}$ & $10.30 \mathrm{ab}$ & $11.29 \mathrm{bc}$ \\
\hline Half NPK + half compost $+100 \mathrm{TS}$ & $7.70 \mathrm{abc}$ & $9.73 \mathrm{a}$ & $11.90 \mathrm{a}$ & $12.63 \mathrm{a}$ & $10.15 \mathrm{ab}$ & $11.13 \mathrm{bc}$ \\
\hline Half NPK + half compost + $150 \mathrm{TS}$ & $8.70 \mathrm{a}$ & $9.90 \mathrm{a}$ & $12.03 \mathrm{a}$ & $12.67 \mathrm{a}$ & $10.64 \mathrm{ab}$ & $11.96 \mathrm{ab}$ \\
\hline Half NPK + half compost $+200 \mathrm{TS}$ & $8.900 \mathrm{a}$ & $10.23 \mathrm{a}$ & $12.27 \mathrm{a}$ & $12.90 \mathrm{a}$ & 10.99 a & $12.38 \mathrm{a}$ \\
\hline Means & 7.99 & 8.99 & 10.94 & 12.04 & 10.23 & 11.41 \\
\hline
\end{tabular}

Means in the same column with the same letters are not significantly different at $P \leq 0.05$ using new L.S.D.

Table 3: Effect of different fertilizer treatments on Leaf number and area of 'Valencia' orange trees during 2013/2014 and 2014/2015 seasons.

\begin{tabular}{|c|c|c|c|c|}
\hline \multirow[b]{2}{*}{ Treatment } & \multicolumn{2}{|c|}{ Leaf area } & \multicolumn{2}{|c|}{ Leaf number } \\
\hline & $\begin{array}{c}2013 / \\
2014\end{array}$ & $\begin{array}{c}2014 / \\
2015\end{array}$ & $\begin{array}{c}2013 / \\
2014\end{array}$ & $\begin{array}{c}2014 / \\
2015\end{array}$ \\
\hline Full NPK (Control) & $8.167 \mathrm{c}$ & $9.367 \mathrm{c}$ & $8.667 \mathrm{e}$ & $10.00 \mathrm{c}$ \\
\hline Full compost & $8.51 \mathrm{~b}$ & $9.93 \mathrm{bc}$ & 9.33de & $10.33 b c$ \\
\hline Full compost $+100 \mathrm{TS}$ & $9.980 \mathrm{a}$ & $9.767 b c$ & $11.00 \mathrm{bc}$ & $11.67 \mathrm{abc}$ \\
\hline Full compost $+150 \mathrm{TS}$ & $8.987 b$ & $10.03 \mathrm{bc}$ & $9.667 \mathrm{cde}$ & $11.33 \mathrm{abc}$ \\
\hline Full compost $+200 \mathrm{TS}$ & $9.840 \mathrm{a}$ & $10.24 \mathrm{~b}$ & $10.67 \mathrm{bcd}$ & $12.33 \mathrm{ab}$ \\
\hline $\begin{array}{l}\text { Half NPK + half compost } \\
+100 \text { TS }\end{array}$ & $9.990 \mathrm{a}$ & $10.17 b c$ & 11.67ab & $12.67 \mathrm{a}$ \\
\hline $\begin{array}{l}\text { Half NPK + half compost } \\
+150 \mathrm{TS}\end{array}$ & $10.14 \mathrm{a}$ & $11.24 \mathrm{a}$ & $12.00 \mathrm{ab}$ & $13.00 \mathrm{a}$ \\
\hline $\begin{array}{l}\text { Half NPK + half compost } \\
+200 \text { TS }\end{array}$ & $10.22 \mathrm{a}$ & $11.90 \mathrm{a}$ & $12.67 \mathrm{a}$ & $13.33 \mathrm{a}$ \\
\hline Means & 9.48 & 10.33 & 9.50 & 11.83 \\
\hline
\end{tabular}

shoot length and leaf area on various fruit crops, such as 'Satsuma' mandarin (Motskobili, 1984) and mango and Avocado (Abd-Rabouo, 2006). Organic fertilization has also affected leaf number and area in sour orange seedlings (El-Morshedy, 1997), 'Washington' navel orange (Abd El-Naby 
et al., 2004), apricot (Kotez and Joubert, 1992), grapes (El-Shenawy and Fayed, 2005a), and peaches (Fayed, 2005a).

The addition of organic fertilizer to the biofertilizer gave the highest effect compared to the biofertilizer alone. This was reflected on the increased number of shoots and leaves, and leaf area, as reported on olive (Hegazi et al., 2007), 'Le Conte' pear (Fawzi et al., 2010), and 'Superior Seedless' grapes (Shaheen et al., 2013).

\section{Chlorophyll content}

Like leaf number and area, total chlorophyll and chlorophyll (a) \& (b) content were significantly increased during both seasons half amount of NPK and organic fertilization mixed with biofertilizer at either 150 or $200 \mathrm{ml} \mathrm{TS}$, as indicated in Table (4) compared to all other treatments during both seasons. Chlorophyll (b) gave similar trent in this respect. Similar results were reported by El-Morshedy, (1997), 'Washington' navel orange (Helail et al., 2003a), and (Abd El-Samad et al., 2006) 'Valencia' orange. Similar results were reported on 'Canino' apricopt (Kabeel, et al., 2005) and red peach (Fayed, 2005b). They found that the Gradual increase in organic fertilization rate in form of chicken manure led to a gradual increase in chlorophyll (a) and (b) content of sour orange trees.

\section{Leaf NPK percentage}

The application of half amount NPK and half amount compost in combination with 100, 150 or $200 \mathrm{ml}$ TS had positively affected the percentage of NPK in 'Valencia' orange leaves, compared to the control during both seasons. Also, the application of full amount of compost and $200 \mathrm{ml}$ TS had a pronounced effect on both $\mathrm{N}$ and $\mathrm{P}$ levels compared to the control during both seasons (Table 5).

In addition, it was noticed that the mixture of half amount NPK and half amount compost enriched with the highest level of TS $(200 \mathrm{ml})$ had more pronounced effect on NPK percentage compared to all other treatments during both seasons. Previous investigations indicated also that the addition of biofertilizers to each or both of the mineral and organic fertilizers significantly increased NPK percentage in 'Valencia' orange leaves. This results are agreed with previous findings of Abd El-Samad et al. (2006) on 'Valencia' orange, Mansour (1998) on 'Anna' apples trees, Ahmed et al. (1997) on 'Red Roomy' grapevines, Kabeel et al. (2005) on apricot, and Amro et al. (2014) on 'Hayany' date palm.

Results were also revealed an increase in leaf NPK percentage with a combined application of organic and bio- fertilizers only. These results are confirmed with previous findings of Tayeh (2003) on 'Washington' navel 
Table 4: Effect of different fertilizers treatments on leaf chlorophyll content $\left(\mu \mathrm{g} / \mathrm{cm}^{2}\right)$ of 'Valencia' orange trees during 2013/2014 and 2014/2015 seasons.

\begin{tabular}{|c|c|c|c|c|c|c|}
\hline \multirow{2}{*}{ Treatment } & \multicolumn{2}{|c|}{ Chlorophyll (A) } & \multicolumn{2}{|c|}{ Chlorophyll (B) } & \multicolumn{2}{|c|}{$\begin{array}{c}\text { Total } \\
\text { Chlorophyll }\end{array}$} \\
\hline & $\begin{array}{c}2013 / \\
2014\end{array}$ & $\begin{array}{c}2014 / \\
2015\end{array}$ & $\begin{array}{c}2013 / \\
2014\end{array}$ & $\begin{array}{c}2014 / \\
2015\end{array}$ & $\begin{array}{c}2013 / \\
2014\end{array}$ & $\begin{array}{l}2014 / \\
2015\end{array}$ \\
\hline Full NPK (Control) & $0.753 \mathrm{c}$ & $0.910 \mathrm{e}$ & $0.280 \mathrm{c}$ & $0.230 \mathrm{c}$ & $1.033 \mathrm{c}$ & $1.140 \mathrm{c}$ \\
\hline Full compost & $0.813 \mathrm{c}$ & $1.100 \mathrm{de}$ & $0.616 b$ & $0.763 b$ & $1.429 b c$ & $1.863 b c$ \\
\hline $\begin{array}{l}\text { Full compost }+100 \\
\text { TS }\end{array}$ & $0.843 \mathrm{c}$ & $1.097 \mathrm{de}$ & $0.633 b$ & $0.876 \mathrm{~b}$ & $1.476 b c$ & $1.973 b c$ \\
\hline $\begin{array}{l}\text { Full compost }+150 \\
\text { TS }\end{array}$ & $0.870 \mathrm{bc}$ & $1.217 \mathrm{~cd}$ & $0.673 b$ & $0.803 b$ & $1.543 \mathrm{~b}$ & $2.020 \mathrm{~b}$ \\
\hline $\begin{array}{l}\text { Full compost }+200 \\
\text { TS }\end{array}$ & $0.886 \mathrm{bc}$ & $1.230 \mathrm{~cd}$ & $0.670 \mathrm{~b}$ & $0.810 \mathrm{~b}$ & $1.556 \mathrm{~b}$ & $2.040 \mathrm{~b}$ \\
\hline $\begin{array}{l}\text { Half NPK }+ \text { half } \\
\text { compost }+100 \mathrm{TS}\end{array}$ & $0.963 \mathrm{bc}$ & $1.430 \mathrm{bc}$ & $0.753 \mathrm{ab}$ & $1.163 \mathrm{ab}$ & $1.716 \mathrm{ab}$ & $2.593 \mathrm{ab}$ \\
\hline $\begin{array}{l}\text { Half NPK + half } \\
\text { compost }+150 \mathrm{TS}\end{array}$ & $1.153 \mathrm{ab}$ & $1.880 \mathrm{a}$ & $1.007 \mathrm{a}$ & $1.350 \mathrm{a}$ & $2.160 \mathrm{a}$ & $3.230 \mathrm{a}$ \\
\hline $\begin{array}{l}\text { Half NPK + half } \\
\text { compost }+200 \mathrm{TS}\end{array}$ & $1.263 \mathrm{a}$ & $1.917 \mathrm{a}$ & $1.017 \mathrm{a}$ & $1.587 \mathrm{a}$ & $2.280 \mathrm{a}$ & $3.504 \mathrm{a}$ \\
\hline Means & 0.94 & 1.35 & 0.71 & 0.95 & 1.65 & 2.30 \\
\hline
\end{tabular}

Table 5: Effect of different fertilizers treatments on NPK percentage in 'Valencia' orange leaves during 2013/2014 and 2014/2015 seasons.

\begin{tabular}{|l|c|c|c|c|c|c|}
\hline \multirow{2}{*}{ Treatment } & \multicolumn{2}{|c|}{$\mathbf{N}(\boldsymbol{\%})$} & \multicolumn{2}{c|}{ P(\%) } & \multicolumn{2}{c|}{ K (\%) } \\
\cline { 2 - 7 } & $\begin{array}{c}\mathbf{2 0 1 3} / \\
\mathbf{2 0 1 4}\end{array}$ & $\begin{array}{c}\mathbf{2 0 1 4} / \\
\mathbf{2 0 1 5}\end{array}$ & $\begin{array}{c}\mathbf{2 0 1 3} / \\
\mathbf{2 0 1 4}\end{array}$ & $\begin{array}{c}\mathbf{2 0 1 4} / \\
\mathbf{2 0 1 5}\end{array}$ & $\begin{array}{c}\mathbf{2 0 1 3} / \\
\mathbf{2 0 1 4}\end{array}$ & $\begin{array}{c}\mathbf{2 0 1 4} / \\
\mathbf{2 0 1 5}\end{array}$ \\
\hline Full NPK (Control) & $2.050 \mathrm{c}$ & $2.370 \mathrm{c}$ & $0.076 \mathrm{c}$ & $0.203 \mathrm{c}$ & $0.463 \mathrm{~d}$ & $0.62 \mathrm{~d}$ \\
\hline Full compost & $2.143 \mathrm{bc}$ & $2.773 \mathrm{~b}$ & $0.080 \mathrm{c}$ & $0.240 \mathrm{c}$ & $0.496 \mathrm{~cd}$ & $0.74 \mathrm{~d}$ \\
\hline $\begin{array}{l}\text { Full compost + 100 } \\
\text { TS }\end{array}$ & $2.203 \mathrm{bc}$ & $2.780 \mathrm{~b}$ & $0.186 \mathrm{~b}$ & $0.307 \mathrm{c}$ & $0.540 \mathrm{bcd}$ & $0.82 \mathrm{~cd}$ \\
\hline $\begin{array}{l}\text { Full compost + 150 } \\
\text { TS }\end{array}$ & $2.237 \mathrm{bc}$ & $2.897 \mathrm{ab}$ & $0.220 \mathrm{~b}$ & $0.350 \mathrm{c}$ & $0.593 \mathrm{bcd}$ & $0.74 \mathrm{~d}$ \\
\hline $\begin{array}{l}\text { Full compost + 200 } \\
\text { TS }\end{array}$ & $2.533 \mathrm{~b}$ & $3.117 \mathrm{ab}$ & $0.220 \mathrm{~b}$ & $0.553 \mathrm{~b}$ & $0.530 \mathrm{bcd}$ & $0.84 \mathrm{bcd}$ \\
\hline $\begin{array}{l}\text { Half NPK + half } \\
\text { compost + 100 TS }\end{array}$ & $2.507 \mathrm{~b}$ & $3.023 \mathrm{ab}$ & $0.210 \mathrm{~b}$ & $0.540 \mathrm{~b}$ & $0.600 \mathrm{bc}$ & $0.88 \mathrm{bcd}$ \\
\hline $\begin{array}{l}\text { Half NPK + half } \\
\text { compost + 150 TS }\end{array}$ & $2.530 \mathrm{~b}$ & $3.230 \mathrm{ab}$ & $0.306 \mathrm{a}$ & $0.680 \mathrm{ab}$ & $0.663 \mathrm{~b}$ & $0.89 \mathrm{bcd}$ \\
\hline $\begin{array}{l}\text { Half NPK + half } \\
\text { compost + 200 TS }\end{array}$ & $2.827 \mathrm{a}$ & $3.457 \mathrm{a}$ & $0.316 \mathrm{a}$ & $0.833 \mathrm{a}$ & $0.933 \mathrm{a}$ & $1.47 \mathrm{a}$ \\
\hline \multicolumn{1}{|c|}{ Means } & $\mathbf{2 . 3 8}$ & $\mathbf{2 . 9 6}$ & $\mathbf{0 . 2 0}$ & $\mathbf{0 . 4 6}$ & $\mathbf{0 . 6 0}$ & $\mathbf{0 . 8 8}$ \\
\hline
\end{tabular}


orange, Helail et al. (2003a) on 'Washington' navel orange, Hegazi et al. (2007) on 'Picual' olive trees, Fayed (2005c) on Apples, and (Fayed 2005a) on peaches.

\section{Leaf Fe, Zn, and Mn content}

Leaf content of $\mathrm{Fe}, \mathrm{Zn}$, and $\mathrm{Mn}$ varied from one season to another, but the only pronounced effect on all three nutrients during both seasons was noticed with the combined application of half amount NPK, half amount compost, and $200 \mathrm{ml} \mathrm{TS}$, as shown in (Table 6). Other treatments have a similar trend with those reported by leaf NPK content compared with control one.

Results are in the same context of previously reported findings of organic fertilization effect on sour orange trees (El-Morshedy, 1997), 'Clementine' mandarin (Abed El-Hamied, 2014), and 'Balady' guava (Osama et al., 2016). In regards to biofertilization, our results were in the same context of previous results of Mahmoud and Mahmoud (1999) on peach seedlings and Sharma and Bhutani (2000) on apples seedlings. The combined application of organic and bio- fertilization significantly increased nutrients content compared to organic fertilization only (Fayed, 2005b and Ahmed et al., 2013).

\section{Fruit set (\%)}

Application of half amount NPK, half amount compost, and $200 \mathrm{ml}$ TS significantly improved fruit set compared to all other treatments and control one which recorded the lowest fruit set percentage in both seasons (Table 7). Compost treatment only as with biofertilizer TS showed intermediate effect. Such trend was clear in the two seasons.

Results are in line with previous reports that indicated a positive effect of fertilization regimes, which include organic and bio- fertilizers, on fruit set percentage of orange trees (El-Kobbia, 1999; Ebrahiem and Mohamed, 2000 ; Helail et al., 2003b) and 'Meet-Ghamr' peach '(Kabeel, 2004).

\section{Total yield (Kg/tree) and its components.}

All treatments significantly increased total yield per tree as fruit number and weight compared to the control during both seasons (Table 7). The most pronounced effect was recorded for half amount NPK, half amount compost, and 150 or, $200 \mathrm{ml} \mathrm{TS}$, compared to the control and all other treatments. Similarly to the previously mentioned parameters, yield results are actually confirming the pronounced effect of all three fertilizers combined (Hepler, 1982).

Results showed some increase in fruit number and weight with the higher levels of biofertilization in the fertilizers mixture. This was 
Table 6: Effect of different fertilizers treatments on leaf micronutrient contents of 'Valencia' orange trees during 2013/2014 and 2014/2015 seasons.

\begin{tabular}{|l|c|c|c|c|c|c|}
\hline \multirow{2}{*}{ Treatment } & \multicolumn{2}{|c|}{ Fe (ppm) } & \multicolumn{2}{c|}{ Zn (ppm) } & \multicolumn{2}{c|}{ Mn (ppm) } \\
\cline { 2 - 7 } & $\begin{array}{c}\mathbf{2 0 1 3} / \\
\mathbf{2 0 1 4}\end{array}$ & $\begin{array}{c}\mathbf{2 0 1 4} / \\
\mathbf{2 0 1 5}\end{array}$ & $\begin{array}{c}\mathbf{2 0 1 3} / \\
\mathbf{2 0 1 4}\end{array}$ & $\begin{array}{c}\mathbf{2 0 1 4} / \\
\mathbf{2 0 1 5}\end{array}$ & $\begin{array}{c}\mathbf{2 0 1 3} / \\
\mathbf{2 0 1 4}\end{array}$ & $\begin{array}{c}\mathbf{2 0 1 4} / \\
\mathbf{2 0 1 5}\end{array}$ \\
\hline $\begin{array}{l}\text { Full NPK } \\
\text { (Control) }\end{array}$ & $53.67 \mathrm{c}$ & $73.33 \mathrm{~d}$ & $17.43 \mathrm{~d}$ & $24.53 \mathrm{~d}$ & $17.67 \mathrm{~b}$ & $23.00 \mathrm{~b}$ \\
\hline Full compost & $55.00 \mathrm{c}$ & $76.67 \mathrm{~cd}$ & $20.17 \mathrm{~cd}$ & $27.33 \mathrm{~cd}$ & $25.87 \mathrm{ab}$ & $32.53 \mathrm{ab}$ \\
\hline $\begin{array}{l}\text { Full compost }+ \\
100 \text { TS }\end{array}$ & $85.67 \mathrm{c}$ & $79.67 \mathrm{~cd}$ & $21.33 \mathrm{bcd}$ & $27.33 \mathrm{~cd}$ & $27.80 \mathrm{ab}$ & $35.67 \mathrm{ab}$ \\
\hline $\begin{array}{l}\text { Full compost }+ \\
150 \mathrm{TS}\end{array}$ & $60.00 \mathrm{c}$ & $98.33 \mathrm{~cd}$ & $28.67 \mathrm{bcd}$ & $28.47 \mathrm{~cd}$ & $30.00 \mathrm{ab}$ & $36.53 \mathrm{ab}$ \\
\hline $\begin{array}{l}\text { Full compost }+ \\
200 \mathrm{TS}\end{array}$ & $87.00 \mathrm{c}$ & $107.7 \mathrm{~cd}$ & $24.27 \mathrm{bcd}$ & $37.07 \mathrm{~cd}$ & $32.00 \mathrm{ab}$ & $36.67 \mathrm{ab}$ \\
\hline $\begin{array}{l}\text { Half NPK + half } \\
\text { compost + 100 TS }\end{array}$ & $161.7 \mathrm{~b}$ & $143.3 \mathrm{c}$ & $33.50 \mathrm{bc}$ & $39.67 \mathrm{bc}$ & $33.70 \mathrm{ab}$ & $37.37 \mathrm{a}$ \\
\hline $\begin{array}{l}\text { Half NPK + half } \\
\text { compost + 150 TS }\end{array}$ & $211.7 \mathrm{~b}$ & $240.0 \mathrm{~b}$ & $35.67 \mathrm{ab}$ & $44.33 \mathrm{~b}$ & $34.10 \mathrm{ab}$ & $42.67 \mathrm{a}$ \\
\hline $\begin{array}{l}\text { Half NPK + half } \\
\text { compost + 200 TS }\end{array}$ & $300.0 \mathrm{a}$ & $330.7 \mathrm{a}$ & $49.33 \mathrm{a}$ & $62.00 \mathrm{a}$ & $38.70 \mathrm{a}$ & $45.67 \mathrm{a}$ \\
\hline Means & $\mathbf{1 2 6 . 8 4}$ & $\mathbf{1 4 3 . 7 1}$ & $\mathbf{2 8 . 8 0}$ & $\mathbf{3 6 . 3 4}$ & $\mathbf{2 9 . 9 8}$ & $\mathbf{3 6 . 2 6}$ \\
\hline
\end{tabular}

confirmed by the previous findings of Tayeh (2003) on 'Valencia' orange, (Fayed, 2005b) on peach, (Mansour, 1998) on 'Anna' apple, (Ahmed et al., 1997) on 'Red Roomy' grapes, (Osman, 2003) on date palm, and (ElShenawy and Fayed, 2005b) on "Crimson Seedless" grapes.

\section{Peel thickness (mm):}

Results of both seasons confirm the significant effect of combined application of the three different fertilizers represented by half amount of NPK, half amount of compost, with either100 or $150 \mathrm{ml}$ TS. Control treatment recorded the lowest fruit peel thickness.

Although, peel thickness may not be preferable for customers; however, it is considered an advantage for shipping. This may mean that control fruit are the best for quick consumption, unless some other treatments that insignificantly differ from the control may add some value to the fruit. Previous findings stated that fruit peel thickness of 'Newhall' navel orange was linearly increased with increased dose of organic fertilization (El-Kobbia, 1999). Organic and bio- fertilization reported to be positively affected peel thickness of the fruit (Hepler, 1982). 


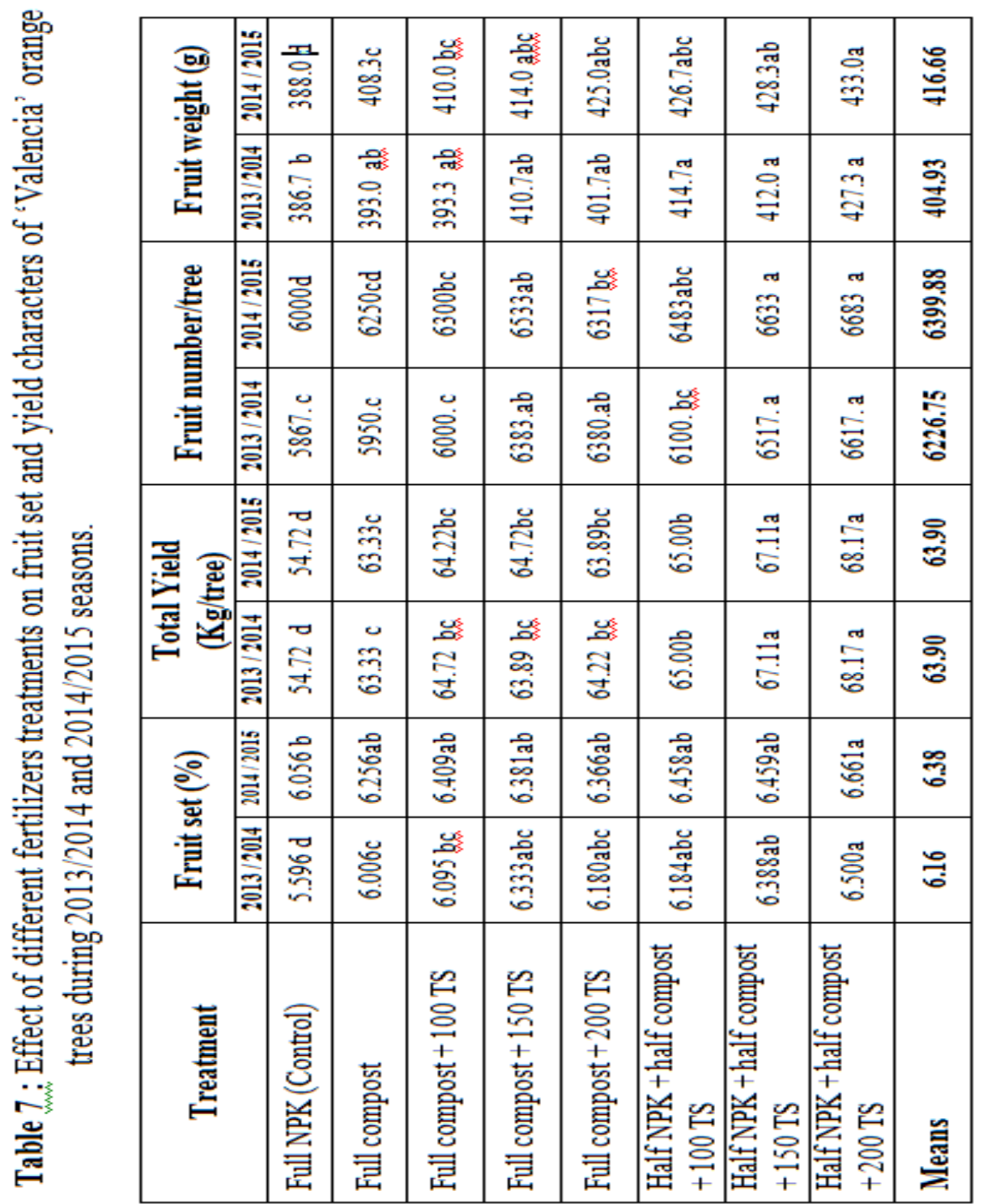


Juice volume $\left(\mathrm{ml}^{3}\right)$

Like peel thickness, the application of half amount NPK, half amount compost with either 100 or $150 \mathrm{ml}$ TS significantly increased juice volume compared to the control during both seasons. However, half amount NPK, half amount compost, and $200 \mathrm{ml}$ TS recorded the highest juice content in comparison to the control and all other treatments during both seasons. Control fruit contained the lowest juice content (Table 8). This may give an indication about the importance of biofertilization in fertilizers mixture.

Results are in agreement of the previous findings reported by ElKobbia, (1999) on 'Washington' navel orange, and Ebrahiem and Mohamed (2000) on 'Balady' mandarins.

Table 8: Effect of different fertilizer treatments on some fruit physical characteristics of 'Valencia' orange trees during 2013/2014 and 2014/2015 seasons.

\begin{tabular}{|l|c|c|c|c|}
\hline \multirow{2}{*}{ Treatment } & \multicolumn{2}{|c|}{ Peel thickness $\mathbf{2 m m}$ ) } & \multicolumn{2}{c|}{ Juice volume $\left(\mathbf{m l}^{3}\right)$} \\
\cline { 2 - 5 } & $\begin{array}{c}\mathbf{2 0 1 3} / \\
\mathbf{2 0 1 4}\end{array}$ & $\begin{array}{c}\mathbf{2 0 1 4} / \\
\mathbf{2 0 1 5}\end{array}$ & $\begin{array}{c}\mathbf{2 0 1 3} / \\
\mathbf{2 0 1 4}\end{array}$ & $\mathbf{2 0 1 4} / \mathbf{2 0 1 5}$ \\
\hline Full NPK (Control) & $0.51 \mathrm{~b}$ & $0.81 \mathrm{c}$ & $126.3 \mathrm{c}$ & $138.3 \mathrm{c}$ \\
\hline Full compost & $0.55 \mathrm{ab}$ & $0.82 \mathrm{bc}$ & $127.0 \mathrm{c}$ & $140.3 \mathrm{c}$ \\
\hline Full compost + 100 TS & $0.56 \mathrm{ab}$ & $0.84 \mathrm{abc}$ & $128.0 \mathrm{c}$ & $144.7 \mathrm{bc}$ \\
\hline Full compost + 150 TS & $0.59 \mathrm{a}$ & $0.84 \mathrm{abc}$ & $128.3 \mathrm{c}$ & $157.3 \mathrm{~b}$ \\
\hline Full compost + 200 TS & $0.59 \mathrm{a}$ & $0.84 \mathrm{abc}$ & $143.3 \mathrm{~b}$ & $144.7 \mathrm{bc}$ \\
\hline $\begin{array}{l}\text { Half NPK + half compost } \\
\text { + 100 TS }\end{array}$ & $0.61 \mathrm{a}$ & $0.88 \mathrm{~b}$ & $142.7 \mathrm{~b}$ & $155.7 \mathrm{~b}$ \\
\hline $\begin{array}{l}\text { Half NPK + half compost } \\
\text { + 150 TS }\end{array}$ & $0.59 \mathrm{a}$ & $0.80 \mathrm{a}$ & $148.7 \mathrm{~b}$ & $159.0 \mathrm{~b}$ \\
\hline $\begin{array}{l}\text { Half NPK + half compost } \\
\text { + 200 TS }\end{array}$ & $0.56 \mathrm{ab}$ & $0.84 \mathrm{abc}$ & $165.7 \mathrm{a}$ & $177.3 \mathrm{a}$ \\
\hline Means & $\mathbf{0 . 5 7}$ & $\mathbf{0 . 8 3}$ & $\mathbf{1 3 8 . 7 5}$ & $\mathbf{1 5 2 . 1 6}$ \\
\hline
\end{tabular}

Total soluble solids (TSS \%) and acidity percentages :

Application of half amount NPK, half amount compost with $200 \mathrm{ml}$ TS has significantly affected the percentage of fruit TSS in comparison to the control during both seasons (Table 9). Other treatment showed intermediate effect like other vegetative and fruit parameters. control treatment the lowest TSS percentage.

The role of organic and bio-fertilizers in improving TSS was reported by Mansour, (1998), on apples, Helail et al. (2003b),on 'Washington' navel orange and Kabeel (2004; Fayed (2005b) on peaches. Nitrogen and potassium play an important role in the process of carbohydrate storage and 
Table 9: Effect of different fertilizers treatments on some fruit chemical traits of 'Valencia' orange trees during 2013/2014 and 2014/2015 seasons.

\begin{tabular}{|c|c|c|c|c|c|c|}
\hline \multirow{2}{*}{ Treatment } & \multicolumn{2}{|c|}{$\begin{array}{l}\text { TSS } \\
(\%)\end{array}$} & \multicolumn{2}{|c|}{$\begin{array}{c}\text { Acidity } \\
(\%)\end{array}$} & \multicolumn{2}{|c|}{$\begin{array}{c}\text { Vitamin C } \\
(\mathrm{mg} / 100 \mathrm{ml})\end{array}$} \\
\hline & $\begin{array}{c}2013 / \\
2014\end{array}$ & $\begin{array}{c}2014 / \\
2015\end{array}$ & $\begin{array}{c}2013 / \\
2014\end{array}$ & $\begin{array}{c}2014 / \\
2015\end{array}$ & $\begin{array}{l}2013 / \\
2014\end{array}$ & $\begin{array}{c}2014 / \\
2015\end{array}$ \\
\hline $\begin{array}{ll}\begin{array}{l}\text { Full } \\
\text { (Control) }\end{array} & \text { NPK } \\
\end{array}$ & $10.30 \mathrm{~b}$ & $11.47 \mathrm{c}$ & $11.37 \mathrm{~d}$ & $12.33 \mathrm{e}$ & $10.13 c$ & $9.633 \mathrm{e}$ \\
\hline Full compost & $10.60 \mathrm{~b}$ & $11.70 \mathrm{bc}$ & $12.73 \mathrm{c}$ & $13.57 \mathrm{~d}$ & $10.30 \mathrm{c}$ & $11.20 \mathrm{de}$ \\
\hline $\begin{array}{l}\text { Full compost }+ \\
100 \mathrm{TS}\end{array}$ & 11.10ab & $12.13 b$ & $13.17 \mathrm{c}$ & $13.90 \mathrm{~cd}$ & $10.40 \mathrm{c}$ & $11.43 \mathrm{de}$ \\
\hline $\begin{array}{l}\text { Full compost }+ \\
150 \text { TS }\end{array}$ & $10.93 \mathrm{ab}$ & $12.23 \mathrm{ab}$ & $13.30 \mathrm{c}$ & $13.97 \mathrm{~cd}$ & $11.80 \mathrm{bc}$ & $12.23 \mathrm{~cd}$ \\
\hline $\begin{array}{l}\text { Full compost + } \\
200 \text { TS }\end{array}$ & $11.20 \mathrm{ab}$ & $12.23 \mathrm{ab}$ & $13.33 \mathrm{c}$ & $14.13 \mathrm{~cd}$ & 13.10ab & $12.90 \mathrm{bcc}$ \\
\hline $\begin{array}{l}\text { Half NPK + half } \\
\text { compost }+100 \mathrm{TS}\end{array}$ & 11.00ab & $12.30 \mathrm{a}$ & 14.30ab & $14.57 \mathrm{bc}$ & $10.80 \mathrm{c}$ & $13.77 \mathrm{abc}$ \\
\hline $\begin{array}{l}\text { Half NPK }+ \text { half } \\
\text { compost }+150 \mathrm{TS}\end{array}$ & 11.07ab & $12.30 \mathrm{a}$ & $14.17 \mathrm{~b}$ & $15.30 \mathrm{ab}$ & $14.10 \mathrm{a}$ & $15.03 \mathrm{ab}$ \\
\hline $\begin{array}{l}\text { Half NPK }+ \text { half } \\
\text { compost }+200 \mathrm{TS}\end{array}$ & $11.77 \mathrm{a}$ & $12.43 \mathrm{a}$ & $14.97 \mathrm{a}$ & $15.80 \mathrm{a}$ & $14.73 \mathrm{a}$ & $15.73 \mathrm{a}$ \\
\hline Means & 11.00 & 12.10 & 13.42 & 14.20 & 11.92 & 12.74 \\
\hline
\end{tabular}

the synthesis of protein and starch, and eventually increase fruit TSS and overall fruit quality (Hepler, 1982).

The results of the present study are in agreement with (El-kobbia, 1999) and (Abdelaal et al., 2010) on 'Washington' navel orange, (Mansour, 1998) on 'Anna' apple, and (Kassem and Marzouk, 2002) on 'Flame' Seedless grapes.

\section{Vitamin C (mg/100 ml juice)}

Trees treated with full amount compost and $200 \mathrm{ml}$ TS, or received half amount NPK, half amount compost with150 or $200 \mathrm{ml}$ TS showed a significant improvement in vitamin $\mathrm{C}$ in comparison to the control, which recorded the lowest vitamin $C$, during both seasons (Table 9). Same findings were reported on lemon trees (Antonio et al., 2002), guava (Faqir et al., 2000), and olive (Fayed, 2010).

Conclusively, it can be concluded that the best results were recorded with the combination of all three fertilizers, especially with middle and high rates of biofertilization (half amount NPK, half amount compost, enriched with, 150 or $200 \mathrm{ml} \mathrm{TS}$ ). This confirm the role of organic and biofertilization on plant growth, development, productivity, and fruit quality, compared to the sole 
use of NPK fertilizers (control), or even organic fertilizers (full amount of compost). The most pronounced effect of the three combined fertilizers was noticed with high rates of biofertilizers (half amount NPK, half amount compost, and $200 \mathrm{ml} \mathrm{TS}$ ).

Results for sure do not nullify the important role of mineral NPK fertilization, and just confirming that minimizing NPK level to half amount with combination of organic and bio- fertilizers was so effective. It should also be noticed that application of half amount NPK, half amount compost, and 200 $\mathrm{ml}$ TS increased peel thickness and fruit acidity, and this increase in both parameters considered unfavorable for the consumer. In most cases, all other treatments show slightly significant effect on vegetative and fruit characteristics in comparison to the control.

So, in this case it would be mentioned that half amount NPK, half amount compost with 150 or $200 \mathrm{ml}$ TS could be recommended to improve tree growth, productivity, and fruit quality, but the disadvantage of peel thickness and fruit acidity may be noted based on the consumer acceptability.

\section{REFERENCES}

Abdelaal, S. ; H . E. Mohamed, and S.S. Kabeil, (2010). Microbial biofertilization approaches to Improve yield and quality of Washington navel orange and reducing the survival nematode in the soil. Journal of American Science, 6(12):264- 272.

Abd El-Naby, S.K. M.; E. A. A. Abd El-Moniem, A. A. Eman, and A. S. E. Abd-Allah, (2004). Effect of source and date of organic manure application on growth, yield, fruit quality and mineral content of Washington navel orange trees grown in sandy soil. Minufiya J. Agric. Res., 2(29):515-540.

Abd El-Samad, G. A.; M. A. Galal, M. M. El-Badry, and S. M. Hussein, (2006). Response of Valencia orange budded on some citrus rootstocks to bio-fertilization and growth media. The $2^{\text {nd }}$ Confirm Integrated Pest Management, 16-18 Jan. Faculty of Agric- El-Fayoum Univ., Egypt, pp. 2I-39.

Abd-Rabouo, F. A. (2006). Effect of microbien, phosphorien and effective micro-organisms (EM) as bio-stimulants on growth of avocado and mango seedlings. Egypt. J. Appl. Sci., 21 (6B) :673-693.

Abed El-Hamied, S. A. (2014). Effect of multi-ingredient of Bokashi on productivity of mandarin trees and soil properties under saline water irrigation. IOSR Journal of Agriculture and Veterinary Science. Volume 7, Issue 11 Ver. II PP 79-87. 
Ahmed, F. F.; A.M. AkI, F.M. El-Morsy, and M.A. Ragab, (1997). The beneficial effects of bio-fertilizers on Red Roomy grapevines (Vitis vinfera L.). a- The effect on growth and nutritional status. Annals of Agricultural Science Moshtohor, 35(1) : 489 - 495 .

Ahmed H.M., F. A. Abdelaal, E.M.A. El- Masry and A. A. Ashraf, (2013). Using potassium sulphur as well as organic and biofertilization for alleviating the adverse effects of salinity on growth and fruiting of Valencia orange trees. Stem Cell, 4(4): 27-32.

Amro, S.M. S.; M. S. Omima, and H.M.G. Osama, (2014). Effect of Effective Microorganisms (EM) and Potassium Sulphate on Productivity and Fruit Quality of "Hayany" Date Palm Grown Under Salinity Stress. Vol. 7, Issue 6 Ver. I, PP 90-99.

Antonio, S.S.; J.S. Andrea, M. Juarez, J. Jorda, and D. Bernudez, (2002). Humic substances and amino acids improve effectiveness of chelate Fe EDDHA in lemon trees. J. of Plant. Nutri., 25 (11): 2433 - 2442.

A.O.A.C. (1995). Association of Official Agricutural Chemists. Association of Official Analysis Chemists Official Methods of Analysis. 15th ed. Washington, DC, USA.

Aseri, G. I.C; N. Jain, J. Panwar, A. V. Rao, and P. R. Meghwal, (2008). Biofertilizers improve plant growth, fruit yield nutrition, metabolism and rhizosphere enzyme activities of pomegranate (Punica granatum L.) in dianthar desert. Scientia Horticulture, 117 : 130- 135.

Brown, J.D. and O. Lilleland (1974). Rapid determination of potassium and sodium in plant material and soil extracts by flame photometer. Proc. Sci. Hort. Sci., $48: 341$ - 346.

Chen, P.M. and W.M. Mellenthin, (1981). Effect of harvest date on ripening capacity and post-harvest life of Anjou Pears. J. Amer. Soc. Hort. Sci., 106: 38.

Chou, G.J. (1966). A new method of measuring the leaf area of citrus trees. Acta Hort., 5:17-20.

Cottenie, A.; L. Verloo, G. Kiekens, and R. Camerlynuck, (1982). Chemical analysis of plant and soil. Laboratory of analyscal and Agro chemistry State University Belgium. Article No. 42, 80-284.

Ebrahiem, T. A. and G. A. Mohamed, (2000). Response of Balady mandarin frees growing in sandy soil to application of filter mud and farmyard manure. Assiut J. Agric. Sci., 13 (5) : 55- 69.

Eghaball, B. and J. F. Power, (1994). Beef cattle feedlot manure management. J. Soil Water Conserv., 49:- $113-122$. 
Eissa, F. M.; M.A; Faith, and S. A. El-Shall, (2007a). The Role of humic acid and rootstock in enhancing salt tolerance of " Le- Conte" pear seedlings. J. Agric. Sci. Mansoura Univ., 32 (5) 3651-3666.

El-Kobbia, A. M. (1999): Response of Washington navel orange to organic fertilizer "biohumus" and cattle manure application. Alex. J. Agric. Res., 44(2): 199-207.

El-Morshedy, F. A. (1997): Organic manure and sulphur interaction influence on vegetative growth and elemental concentration of sour orange seedlings. J. Agric. Sci., Mansoura Univ., 22 (12): 4599-4616.

El-Shenawy, I. E.; and T. A. Fayed, (2005a). Evaluation of the conventional to organic and bio-fertilizers on "Crimson seedless" Grapevines in comparison with chemical fertilizers. A. Vegetative growth and nutritional status. Egyptian Journal of Applied Science, 20(1): 192- 211.

El-Shenawy; I. E. and T.A. Fayed, ( 2005b). Evaluation of the conventional to organic and bio-fertilizers on "Crimson Seedless" grapevines in comparison with chemical fertilizers. B. Yield and fruit quality. Egyptian Journal of Applied Science, 20 (1) 212-225.

Faissal F. A.; H. A. Farouk, Y. M. Ahmed, and A. R. H. Sahr, (2015b). Using Some Organic Manures and Effective Microorganisms as a Partial Replacement of Mineral N Fertilizer in Sukkary Mango Orchards. Stem Cell , 6(3):20-32.

Faissal, F. A. and G. M. El-Dawwy, (1999). Efficiency of phosphorene (as a source of phosphate souiubilizing bacteria ) in enhancing growth and $\mathrm{P}$ nutrition of Chemlali olive seedlings. Acta Hort., 481 : 701-703.

FAO (2017). Food and Agriculture Organization of the United Nations, www.fao.org (last visited April 18 ${ }^{\text {th }}, 2017$ ).

Faqir, M.; Shakir, M.A. and M.R. Salik, (2000). Effect of individual and combined application of organic and inorganic manures on the productivity guava (Psidium gaujava L.). Pakistan J. Bio. Sci., 3(9): 1370 $-1371$.

Farag, S. G., (2006). Minimizing mineral fertilizers in grapevine farms. M. Sc. Thesis institute of environmental studies and research, Ain Shams University, Egypt.

Fawzi M.I.F., .F.M. Shahin, Elham, A. Daood and E.A. Kandil (2010).Effect of organic and biofertilizers and magnesium sulphate on growth yield, chemical composition and fruit quality of "Le-Conte" pear trees. Nature and Science, 8(12):273-280.

Fayed T. A. (2005a). Response of Desert Red peach tree to some bio-fertilizers in comparison with chemical fertilizers. a. Growth and nutritional status. Egyptian Journal of Applied Science, 20 (1): 127- 143. 
Fayed T. A. (2005b). Response of Desert Red peach tree to some biofertilizers in comparison with the chemical fertilizers. b. Yield and fruit quality, and bud state. Egyptian Journal of Applied Science, 20 (1): 144158.

Fayed T.A. (2010). Response of Four Olive Cultivars to Common Organic Manures in Libya. American-Eurasian J. Agric. \& Environ. Sci., 8 (3): 275-291.

Fayed, T. A. (2005c).Effect of some organic manures and bio- fertilizers on Anna Apple trees. A. Vegetative growth and leaf chemical constituents. Egyptian Journal of Applied Science, 20 (1) 159-175.

Hegazi E.S.; M.R. El-Sonbaty; M.A. Eissa; Dorria M.Ahmed and T.F. ElSharony (2007).Effect of Organic and Bio-Fertilization on Vegetative Growth and Flowering of Picual olive Trees. World Journal of Agricultural Sciences, 3(2):210 - 217.

Helail, B. M.; Y. N. Gobran, and M. H. Mostafa, (2003a). Study on the effect of organic manure application and bio-fertilizers on A. Tree growth and leaf mineral content of Washington navel orange trees. Egypt. J. Appl. Sci., 18 (144): 270 - 296.

Helail, B. M.; Y. N. Gobran, and M. H. Mostafa, (2003b). Study on the effect of organic manure application and bio-fertilizers on B. Fruiting and Fruit quality of Washington navel orange trees. Egypt. J. Appl. Sci., 18 (141): 297-320 .

Hepler, PK (1982). Endoplasmic reticulum in the formation of the cell plate and plasmodesmata. Protoplasma, 111, 121-133

Hiwarale, J.s; M.N. Patil, and G.S. Laharia, (2004). Effect of organic and inorganic fertilizers on growth, yield and quality of acid lime. Annals of Plant Physiology, 18 (1): 28 - 30.

Hodgson, R.W. (1967). The citrus industry, history, world distribution, botany and varieties. In: W. Reuther, H.J. Webber, and L.D. Batchelor (eds.).Div. Agr. Sci., University of California Press, Berkeley, California. Horticultural Varieties Of Citrus, 431-580.

Ismail, A. F.; S. M. Hussien, S.A. El- Shalt, and M . A Fathi, (2007). Effect of irrigation and humic acid on Le-Conte pear. J. Agric. Sci., Mansoura Univ., 32(9): 7589 - 7603.

Jahoda, G. (1976). Florida: A bicentennial history, W. W. Norton \& Co., New York. p.104-111.

Jones, W. W.; T. W. Embleton, (1960) . Leaf analysis nitrogen control programs for oranges. Calif. Citrogr, 45(20): 394-353. 
Kabeel, H. (2004). Influence of different rates of nitrogen and potassium on vegetative growth, fruiting aspects, fruits characteristics and leaf mineral composition of "Meet-Ghamr" peach trees, Minufiya J. Agric. Res., 29 (1): 215 - 234.

Kabeel, H.; G. S. Abdel Latif, and A. A. Khalil, (2005). Effect of soil application of different mineral and bio-fertilizer treatments on growth, fruiting parameters, fruit properties and leaf nutrient content of "Canino', apricot trees. Journal of Agriculture Science, Mansoura Univ., 30 (3): 1583-1594.

Kassem, H. A.; and H. A. Marzouk, (2002). Effect of organic and mineral nitrogen fertilization on the nutritional status, yield, and fruit quality of Flame Seedless grapevines grown in calcareous soils. Journal of Advanced Agriculture Research, 7 (1):118-126.

Kotez, W. A. G. ; and M. Joubert, (1992). Effect of different organic materials for soil improvement, mulching and fertilization on the performance of apricot trees. J. Southern African Society for Horticulture Science, 2 (1) : 31 - 35 .

Kwan, A. (2011). "Vernier scales and other early devices for precise measurement". American Journal of Physics., 79 (4): 368. doi: 10.1119/ 1.3533717 .

Little, T.M and Hills, F.J. (1972). Statistical Methods In Agricultural Research, University of California, Davis, 22(1): 139-242 pp.

Mahmoud, H. M. and F. A. F. Mahmoud, (1999). studies on effect of some biofertilizers on growth of peach seedlings and root rot disease incidence. Egyptian Journal of Horticulture, 26 (1) :7- 18.

Mansour, A. E. M. (1998). Response of Anna apple to some biofertilizer. Egyptian Journal of Horticultures, 25 (1) : 241 - 251.

McKnight, T.L.; and D. Hess, (2000). Physical Geography: A Landscape Appreciation, Prentice Hall, New Jersy., 11(2) : 221-226.

Mohit, K.; and R. Kumar, (2013). Response of organic manures on growth and yield of mango (Mangifera indica L.) cv. Dashehari. Hortflora Research Spectrum, 2(1): 64-67.

Moran, R. (1982). Formulae for determination of chlorophyllous pigment extracted with N, N. Dimethyl formamide. Plant Physiol., 69: 1376 1381 .

Morse, J.G. and C.A. Robertson (1987). Calculating canopy area of citrus trees and surface area of fruits. Florida Entomology. 70-168 .J. Amer. Soc. Hort. Sci, 115 (1): 6-8. 
Motskobili, N.A. (1984). Assimilation area of Satsuma in relation to mineral nutrients and its effect on productivity. Subtropicheskie Kultury, No. 5: 83-90.

Mourafilha, F .A. A.; C .T. S. Dias, and A .A. Salibe, (1998).Effect of substrate composition on development of young trees of sweet orange $c v$. Pera, Sci. Agric., 55 (1) 35 - 42.

Murphy, J. and J.P. Riley, (1962). A modified single solution method for the determination of phosphate in the natural water. Ana. Chem. Acta., $27: 3 \mathrm{I}$ $-36$.

Oparka, K.J. (1993). Signalling via plasmodesmata-the neglected pathway. Seminars in Cell Biogy, 4: 131-138.

Osama, H.M. ; A. El Gammal, and S.M. Salama, (2016). Effect of Sheep Manure Application Rate and Method on Growth, Fruiting and Fruit Quality of Balady Guava Trees Grown Under Mid-Sinai Conditions. IOSR Journal of Agriculture and Veterinary Science , 9 (1): 59-72.

Osman, S. M. (2003). Effect of bio-fertilization on fruit physical and chemical properties of Zaghlool Date Palm. Annals of Agricultural Science, 8 (1): 297- 305.

Pregle, F. (1945). Quantitative Organic Microanalysis, $4^{\text {th }}$ ed. J.A Churchill, Ltd. London. PP 266- 387.

Safar H. AL-Kahtani and M.A. Ahmed (2012). Effect of Different Mixtures of Organic Fertilizers on Vegetative Growth, Flowering, Fruiting and Leaf Mineral Content of Picual Olive Trees. American-Eurasian J. Agric. \& Environ. Sci., 12 (8): 1105-1112.

Saleh, E. A., and M. A. Ahmed, (1988). Influence of inoculation Azotobacter. Azospirillum inoculate on the control of soybean root rot diseases caused by Fusarium solani $F$, sp. Phaseolina. Proc $2^{\text {nd }}$ Conf. Agric. Devlop., Res., Ain Shams Univ., pp. 97- 115 .

Shaheen, M.A.; M. W. Sahar, F.M. El-Morsy and A.S.S. Ahmed (2013). Effect of Organic and Bio-Fertilizers as a Partial Substitute for NPK Mineral Fertilizer on Vegetative Growth, Leaf Mineral Content, Yield and Fruit Quality of Superior Grapevine. Journal of Horticultural Science \& Ornamental Plants, 5 (3): 151-159.

Sharma, S. D. and V. P. Bhutani, (2000).Leaf nutrient status of apple seedlings as influenced by VAM, Azotobacter and inorganic fertilizers. Journal of Hill Research, 13 ( 2) : 63 - 66 .

Shiralipour, A.; D. McConnell, and W. Smith, (1992). Physical and chemical properties of soils as affected by municipal solid waste compost application. Biomass and Bioenergy, 3 : 261 - 266. 
Snedecor. G. W. and W.G. Cochran, (1980). Statistical Methods. Sixth Edition Ioa State Unit. Press, Ames, Iowa, U. S. pp 1207 - 1285.

Spiegel-Roy, P. and E.E. Goldschmidt. (1996). Biology Of Citrus. Cambridge University Press, Cambridge, UK. ISBN 0521 . pp 230 - 333

Subba-Rao N.S.; G.S. Venkaferaman, and S. Kannaiyan, (1993). Biological Nitrogen Fixatin. India Council. Agric. Res., New Delhi, p. 112.

Tayeh, E.A.H. (2003). Response of Washington navel orange trees to sources and rates of mineral fertilizer, bio-fertilizer and organic manure. Annals of Agricultural Science, Moshtohor, 41( 2):799-817 .

Wilde, S.A.; R.B. Corey; J.G. Layer and G.K. Voigt ( 1985). Soil And Plant Analysis For Tree Culture . Published by Mohan Primlani, Oxford, IBH, Publishing Co., New Delhi, 29(3): 130 - 142.

Yadav, R. I.; R. K. Singh; Pravesh Kumar and A. K. Singh (2012). Effect of nutrient management through organic sources on the productivity of guava (Psidium guajava L.). HortFlora Research Spectrum, Vol.1 No.2 pp.158-161.

Zekri, M; T. A. Obreza, and R. Koo (2003). Irrigation, Nutrition, and Citrus Fruit Quality. SL 207, series of the Soil and Water Science Department, UF/IFAS Extension, Universit of Florida, Gainesville, Florida, USA. Journal of Fruit Sci., 34(2): pp 936- 1101.

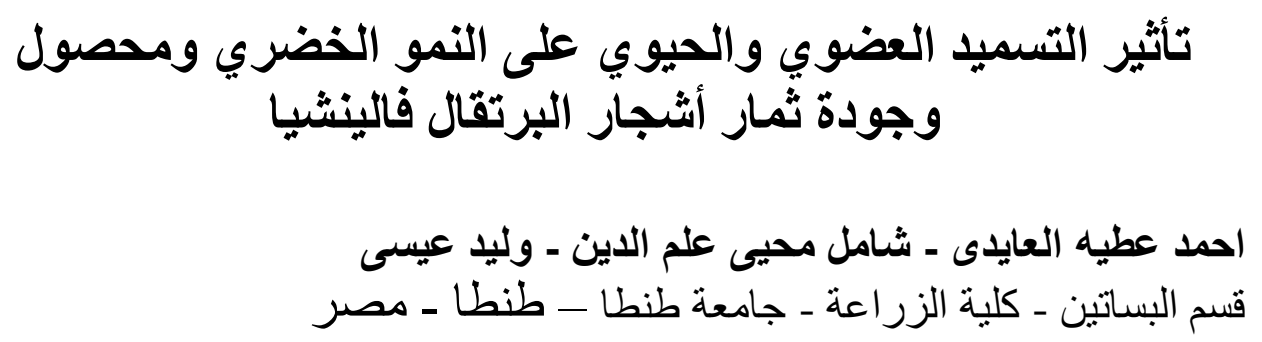

أجريت هذه الدارسة خلال موسمى 2013 / 2014م ، 2014 / 2015 م علي

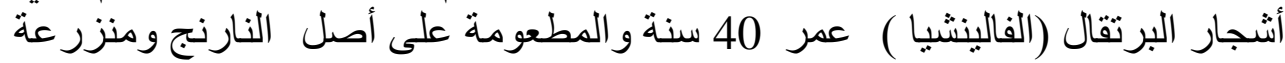
في تربة طينية خفيفة في مزر عة مو الح خاصة بمدينة المحلة الكبرى بمحافظة الغرية الغربية

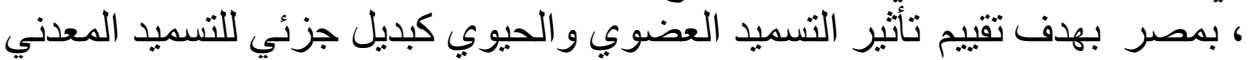

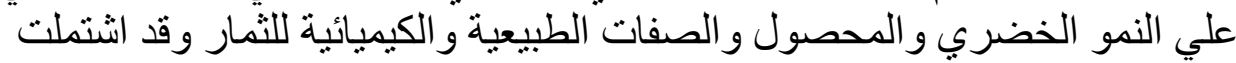

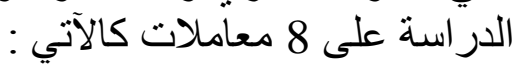

1- إضافة الاحتياجات السمادية كاملة و الموصي بهاما في صورة معدنية (الكنترول) 
2- إضافة الاحتياجات السمادية الموصي بها في صورة عضوية ( كمبوست )

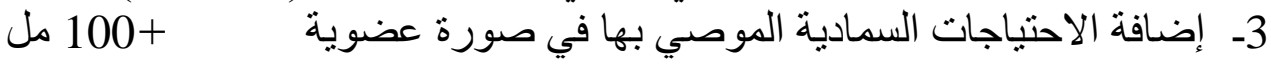
T.S

4- إضافة الاحتياجات السمادية الموصي بها في صورة عضوية T.S

5- إضافة الاحتياجات السمادية الموصي بها في صورة عضوية +200 مل T.S

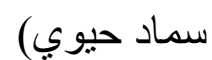

6- إضافة نصف الاحتياجات السمادية في صورة معدنية + نصفها في صورة عضوية

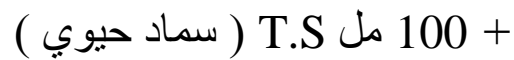

7- إضافة نصف الاحتياجات السمادية في صورة مل معدنية + نصفية النها في صورة عضوية

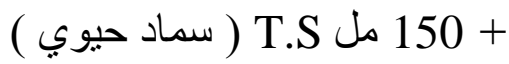

8- إضافة نصف الاحتياجات السمادية في صورة

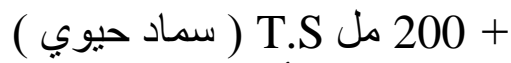
و أظهرت النتائج أن إضافة نصف الاحتياجات السمادية في صورة معدنية + نصفها

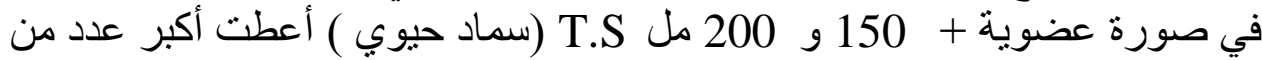

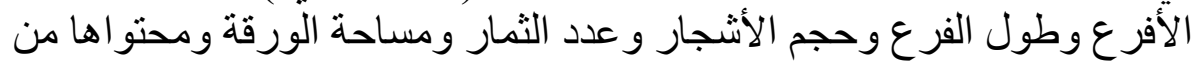

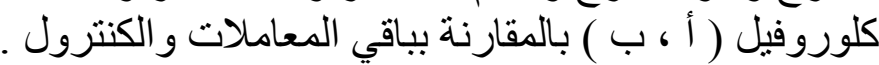

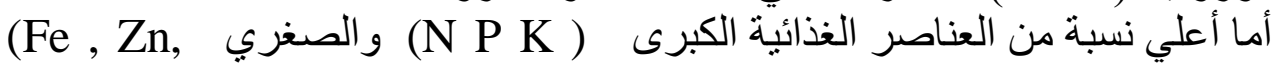

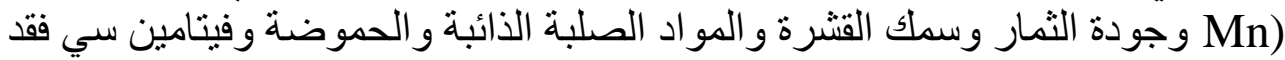

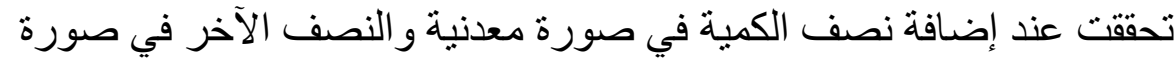

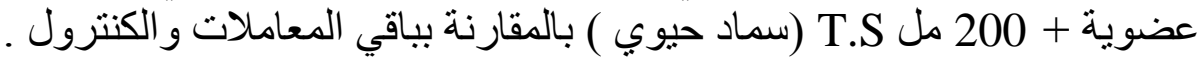

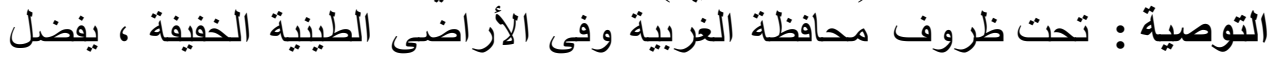

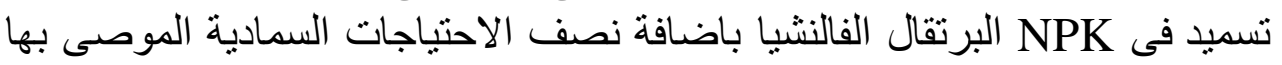

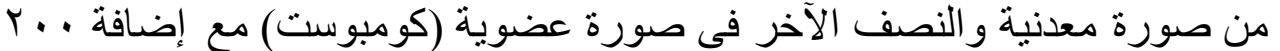

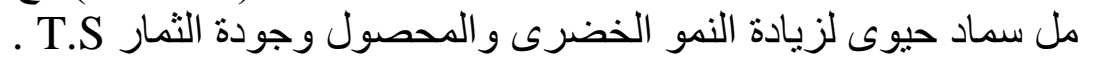

